\title{
A Preliminary Assessment of the Change Recipients' Perceptions of the "4+4+4 Reform Initiative": Has Anything Changed?
}

\author{
M. Semih Summak
}

Faculty of Education, Gaziantep University, Turkey

Copyright $(2016$ by authors, all rights reserved. Authors agree that this article remains permanently open access under the terms of the Creative Commons Attribution License 4.0 International License

\begin{abstract}
The purpose of the present study was to assess change recipients' perceptions of $4+4+4$ reform initiative put in effect in Turkish education system and to explore if anything has changed within the one-year interval. This research is a qualitative longitudinal case study conducted in 2013 and 2014 in a large city in Southeastern Turkey. Pragmatist paradigm has been the guiding research philosophy. The study group consisted of 106 teachers, 64 school administrators, and 4 educational supervisors. The study group was chosen via purposive sampling technique. Data were gathered through structured interview protocol consisting of four open-ended questions. Findings indicated that the favorable and unfavorable aspects of the reform regarded as positive were mostly remained unchanged in the one-year interval. Some of the problems remained the same. Finally, it was revealed that the participants' expectations about the future of the system varied in terms of potential effects of the reform initiative. Based on the findings, suggestions for the implementers and policy makers were offered.
\end{abstract}

Keywords Educational Reform, 4+4+4 Reform Initiative, Change Recipients' Perceptions, Turkish Education System

\section{Introduction}

A review of the literature yielded that change has gained a very strategic meaning for organizations in the 21 st century $[1,2,3]$. Today organizations have to regard change as an important element of their policy making because of its far-reaching effects on survival, development and renewal of their entity in various aspects $[4,5,6]$. This is true of all kinds of organizations including educational ones. Some factors like globalization and the need to remain competitive in the national and international spheres [1, 3] force organizations to respond to/initiate change and manage it well. The case of TIMSS and PISA can be given as an example for educational organizations. These international exams have triggered a kind of competition among countries to increase their students' achievement in the exams, which influences their educational policies and reform initiatives [2].

Change is a multi-level phenomenon consisting of critical components, and neglecting one of these critical components may result in failure of change initiatives [7, 8, 9]. The dynamic structure of change requires a dual investigation of change, the ends of which highlights different visible and invisible elements and completes each other in a puzzle-like structure. These ends of change can be considered as software and hardware of the organization, among other things.

The software of the organization stands for the human side of change, the managerial mindset and culture of the organization. This sphere is highly critical in that the success and quality of change initiatives depend on organizational members' acceptance of change [10], transformation of their mental models [8], cultural elements of the organization [11] and managerial mindset [10]. Although the software is a subsystem of the organization, it has a critical share in running the whole system.

People are implementers of change initiatives in their work units, and they may likely translate what they understand from change into their work behaviors; it is, therefore, suggested that individual goals, values, fears and beliefs of main stakeholders must be addressed [12, 13, 14]. As put by Armenakis \& Harris [7] and Piderit [15], change recipients' motivations to support organizational changes or not and their enthusiasm are effective in the successful implementation of the change. Analyzing and understanding the software of the organization can be possible through meeting with change recipients, appealing to their views and letting them voice their concerns about the incoming or ongoing change.

The hardware of the organization is the other sphere which needs to be dealt with in the change process. This sphere covers all the structural elements facilitating the change 
recipients to accept and embrace change and willingly implement it. All of these elements may become meaningful or help to reach ultimate goals of change initiatives only after the software of the system is handled.

Educational reforms archives around the world confirm the importance of considering both the software and hardware of the organizations. Most of the valuable and well-thought initiatives usually fail because of the missing link between the aforementioned spheres. The reasons for failure can be listed as follows:

a) Believing that structural change will lead to automatic effects in other aspects of education [16],

b) Top-down, imposed change [17],

c) Governments' expectations for immediate results [18],

d) Too broad, vague or ambitious change [19, 20],

e) Superficial, fragmented or political change [12].

f) Lack of a historical perspective on educational change experiences [21, 22], and

g) Lack of a clear theory of change [23].

The last system-wide educational reform initiative, widely known as $4+4+4$ education system, was initiated in the 2012-2013 academic year without any pre-implementation or pilot study across Turkey. As the system was totally new to the change recipients, it is required to question whether the new system has worked for the better in terms of teaching and learning processes or has caused new problems in practice and failed to offer solutions to the chronic problems of Ministry of National Education (MONE). This "reform initiative"- popularly known as $4+4+4$ has envisioned the following changes in educational spheres in Turkey:

1. Extension of basic compulsory education from 8 years to 12 years and the division of basic education into three 'four-year periods', with intervals at each level (former system enacted uninterrupted 8 years).

2. Re-establishment of intermediary religious vocational, Imam-Hatip, schools (once these schools were shut down as suggested by the "February $28^{\text {th }}$ postmodern coup" and military-led regime in 1997).

3. The introduction of elective courses (at junior high school level) of both religious and liberal oriented, such as the life of Prophet Mohammed, the Holy Qu'ran, music, painting and ethnic languages.

4. Division of primary (4 years), junior (4 years) and senior high schools (4 years) as different administrative entities serving in separate buildings/facilities.

5. Re-structuring of curricula and the content of textbooks in line with a constructivist tradition (aiming at learning, mainly through exploration).

6. Increase in the weekly teaching hours, especially at primary and secondary levels.

7. Decreasing the schooling age down to 60 -month old kids and assuming them all, ready for attending school as first graders, unless a contradictory medical report is provided for exemption (this item was suspended one year later, due to growing opposition coming from parents).

8. Enabling transitions from regular/academic education to vocational/technical education, even after primary level if the intermediary-religious vocational path is preferred [24].

\subsection{Purpose and Significance of the Study}

The overarching purpose of the study is to provide casespecific 'actionable knowledge' for practitioners and policy makers, gathered in depth from the actual implementation field. This purpose was attempted to be achieved through assessing change recipients' perceptions about the ongoing change (the $4+4+4$ reform initiative) on a cross-sectional and longitudinal basis to understand how the change process unfolded over time. To achieve this end, the research aimed at examining the most favorable, the most difficult/complicated and the most disruptive aspects of the "change initiative" under scrutiny. The questions guided the research were drafted as: How do the recipients experience the " $4+4+4$ change initiative" and how have their perceptions changed over one-year implementation period? This study is significant in that change recipients' perceptions were assessed twice, with one-year interval and analyzed using a qualitative methodology to gain a deeper insight into the ongoing change process that would not have been possible otherwise.

\section{Methodology}

\subsection{Method}

This research is a two-tier qualitative case study. "Case study research involves the study of an issue explored through one or more cases within a bounded system" [25, $\mathrm{p}$. 73]. The case elaborated in this study is the ongoing system-wide educational change initiative in Turkey. The author preferred case study design since "an organizational change process" can itself be considered as a case [26]. I entered the field seven months after the introduction of the "new system" during the academic year 2012-2013. The participants/informants (teachers, administrators and educational supervisors) were recruited, on a purposive sampling basis, from private and public schools in the Greater City Area of a metropolitan province situated in the Southeastern part of Turkey. Within the boundary of the case, at the time study was conducted, there were 1097 schools at all levels, 520632 students enrolled, 16164 teachers and 1188 administrators in total [27].

Cross-sectional longitudinal data were collected in two rounds. For each round of the data collection, a separate structured interview protocol (bearing four-category open-ended questions) was used. In the first round, for example the interview protocol, was intended to extract information about, (1) the most favourable aspects of the "initiative"; white area, (2) the most difficult or complicated novelties to implement; gray area, (3) the most disruptive 
aspects of the change; black area, and (4) the future of the 'new initiative'. While in the second round, the interview protocol, using the same four-category layout, asked "has anything changed after one-year implementation period?" concerning each of the above mentioned four dimensions of the change. Different groups of participants were recruited from the target population in each of the rounds. "It is common for cross-sectional data to be recorded in a succession of surveys at two or more points in time, with a new sample on each occasion [28, p.221].

As for the guiding research philosophy, pragmatist paradigm has been followed. Pragmatism assumes that utility and practical usefulness of knowledge are more valuable than the abstract notion of truth and "a pragmatist outlook implies an interest in change and how people bring about and respond to change" [29, p.251]. Pragmatist paradigm is actually interested in the actionable character of the empirical findings. However, pragmatism values moral rightness of knowledge with the same level of importance as truthfulness [30].

\subsection{Study Group}

A total of 178 participants composed of teachers, school administrators, and educational supervisors attended this study. The questions in the protocol were administered to 89 participants in 2013. Then, one year later, the four questions (including details about the first-year experiences of the change recipients) were posed to 89 different participants of the case recruited from the target population. The questions and modality of the interview protocol were almost the same. All the participants having attended both rounds were implementers of the reform at their schools and also the students enrolled in a non-thesis graduate program at a state university in Southeastern Turkey. As the participants' seniority, teaching branches and being graduate students were likely to enable the researchers to gather rich data. Therefore, convenient sampling was preferred in the selection of the participants.

Frequencies and percentages regarding the participants' characteristics are presented in Table 1.

As can be seen in Table 1, among the participants, those working at public schools formed the largest group. The smallest group of the participants was high school teachers.
In addition, the number of teachers participating in this study was greater than that of school administrators and supervisors.

Table 1. Frequencies and percentages regarding the participants' characteristics

\begin{tabular}{|c|c|c|c|c|}
\hline Variables & \multicolumn{2}{|c|}{$1^{\text {st }}$ round participants } & \multicolumn{2}{|c|}{$\begin{array}{c}2^{\text {nd }} \text { round } \\
\text { participants }\end{array}$} \\
\hline School type & $\mathrm{f}$ & $\%$ & $\mathrm{f}$ & $\%$ \\
\hline Kindergarten & 15 & 16,9 & 10 & 11,2 \\
\hline Elementary school & 39 & 43,8 & 44 & 49,4 \\
\hline Middle school & 24 & 27,0 & 26 & 29,2 \\
\hline High school & 11 & 12,4 & 9 & 10,1 \\
\hline Total & 89 & 100 & 89 & 100 \\
\hline Position & $\mathrm{f}$ & $\%$ & $\mathrm{f}$ & $\%$ \\
\hline Teacher & 61 & 68,5 & 45 & 50,6 \\
\hline Administrator & 26 & 29,2 & 38 & 47,2 \\
\hline Supervisor & 2 & 2,2 & 2 & 2,2 \\
\hline Total & 89 & 100 & 89 & 100 \\
\hline School status & $\mathrm{f}$ & $\%$ & $\mathrm{f}$ & $\%$ \\
\hline Public & 74 & 83,1 & 83 & 93,3 \\
\hline Private & 15 & 16,9 & 6 & 6,7 \\
\hline Total & 89 & 100 & 89 & 100 \\
\hline
\end{tabular}

\subsection{Data Analysis Procedures}

Content analysis technique was used to investigate the data obtained from both of the data collection cycles. Based on the obtained data, main themes, categories and codes were identified. A color scheme was developed by the researcher to explicitly determine the themes, categories and codes. Findings are represented with three colors, each standing for a different aspect of the change: White for the positive outcomes; corresponding to "the most favorable aspect(s)" in the interview protocol; black for disruptive/negative aspects, and lastly gray, for the ambivalent aspects; "corresponding to the most difficult or complicated novelties in the interview protocol." Each participant was given a code for anonymity (i.e. $\mathrm{T}=$ Teacher, $\mathrm{A}=$ Administrator, $\mathrm{S}=$ Supervisor). The color scheme is presented below (Figure 1): 


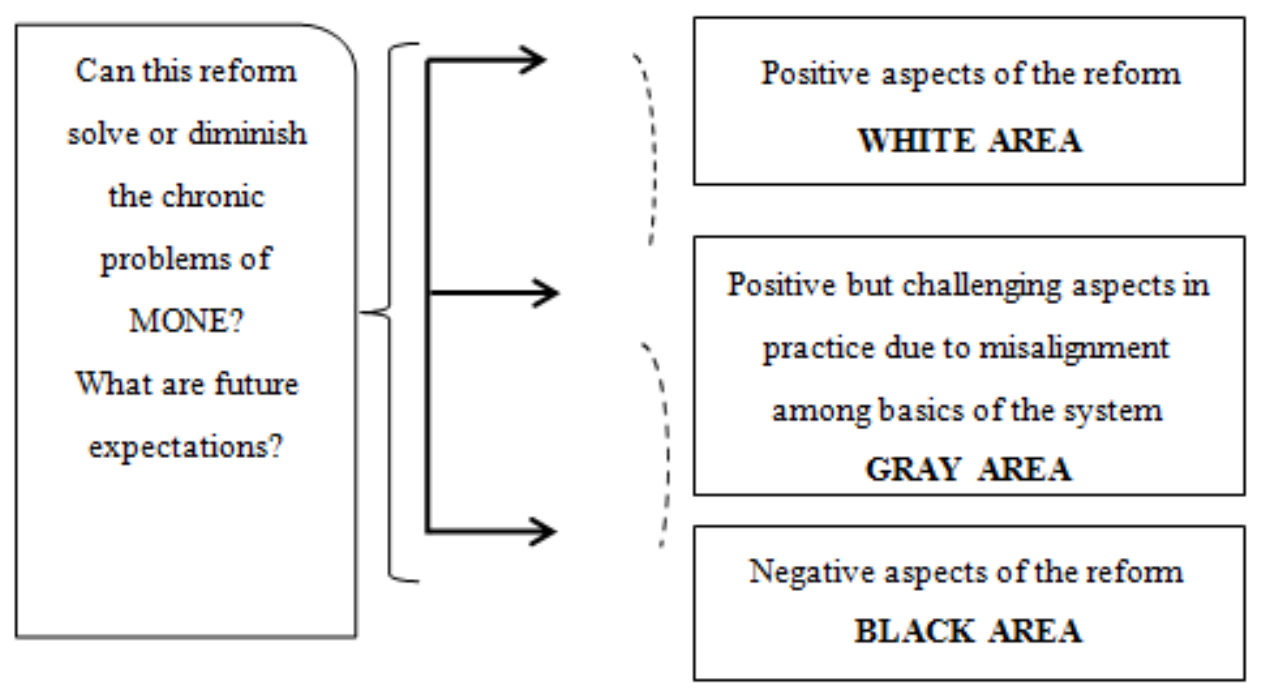

Figure 1. The Color Scheme

In the qualitative analysis of the data, coding was first done using open and selective coding techniques, and then similar codes were combined into the same categories. In the findings section, the codes emerging as a result of constant comparison of data, codes and concepts are presented with their frequencies. Finally, direct quotations which have significance to the examined aspects are also given below the tables.

\subsection{Validity and Reliability}

In order to establish validity and reliability, the collected data were coded and supported with direct quotations from the participants' views. Emerging themes, categories, and codes were compared constantly to ensure that they were consistent and formed a meaningful integrity. All the research process including the research protocol, selection of the study group, data analysis was told in detail throughout the paper. A conceptual framework based on a literature review was used in the construction of the protocol and data analysis. The researchers analyzed the written answers independently. Then the results were compared. There was $85 \%$ agreement in coding. Last, raw data and the findings were examined by an independent researcher.

\section{Findings}

The questions in the interview protocol constructed the main themes of the study. Based on change recipients' perceptions of the " $4+4+4$ reform initiative", the findings were reported in 4 tables. One of the salient findings emerged throughout the case was that the change/reform initiative came down all of a sudden and caught everybody unprepared. This perception may have driven the change recipients to the feeling of isolation. One teacher explained her sense of isolation through an analogy:

"I am not happy with the new system... the former one was much better, because we used to know how to handle situations and the daily routines... I feel myself helpless nowadays...we were thrown into water and now struggling" (T7, 2013).

Similarly, another respondent commented on the same situation as such:

"Up to now no one has ever given us any feedback concerning the difficulties we are facing at schools since the beginning of this academic year; nobody has ever asked for an account of what is going on here. I believe this insensibility will not change in the near future" (T35, 2013).

\subsection{White Area}

In Table 2, change recipients' perceptions of the most favorable aspects of the "reform initiative" (2013) and the things that are favorable (2014) are presented comparatively. 
Table 2. The most favorable aspects of the reform initiative and the things that are favorable

\begin{tabular}{|c|c|c|c|}
\hline The most favorable aspects (2013) & $\mathrm{f}$ & The things that are favorable (2014) & $\mathrm{f}$ \\
\hline Division of school facilities & 41 & Division of school buildings & 45 \\
\hline $5^{\text {th }}$ graders in middle schools & 17 & Foreign language instruction & 17 \\
\hline Elective courses & 12 & Revised schooling age & 15 \\
\hline Simplification of curriculum & 8 & School staff's adaptation to the system & 9 \\
\hline 12-year compulsory education & 4 & Simplification of the curriculum & 7 \\
\hline Paving way for vocational education & 4 & Elective courses & 7 \\
\hline Foreign language instruction & 4 & Lower workload for school staff & 6 \\
\hline Increasing social activities & 4 & $5^{\text {th }}$ graders in middle schools & 5 \\
\hline Recruitment of new teachers & 3 & Recruitment opportunities for teachers & 5 \\
\hline Multi-path school transition & 3 & Decrease in complexities about the system & 3 \\
\hline Termination of social club activities & 2 & New examination system & 3 \\
\hline Decrease in conflicts among teachers & 2 & 4-year stages in compulsory education & 3 \\
\hline Dealing with one school level & 2 & Increasing interest in secondary education & 3 \\
\hline Early-age literacy & 2 & Lower class size & 2 \\
\hline Girls' schooling ratio & 2 & Branch courses for $5^{\text {th }}$ graders & 2 \\
\hline Open high schools & 1 & Compensation for lack of materials & 2 \\
\hline \multirow[t]{9}{*}{ Use of newly program-aligned textbooks } & 1 & Students' clothing & 1 \\
\hline & & Process-based education & 1 \\
\hline & & Solution of challenges of service busses & 1 \\
\hline & & Decrease in conflicts among teachers & 1 \\
\hline & & Teachers' engagement in research & 1 \\
\hline & & Termination of social club activities & 1 \\
\hline & & Fewer courses in primary schools & 1 \\
\hline & & Rotation of teachers and administrators & 1 \\
\hline & & Better course books & 1 \\
\hline
\end{tabular}

Findings presented in Table 2 indicated that the most favorable aspects of the 4+4+4 reform initiative in 2013 were the division of primary and middle school facilities, elective courses, the former 5th graders' attending middle schools and the simplified curriculum.

In addition, the division of school facilities, foreign language instruction, revised schooling age and school staff's adaptation to the system were regarded as things progressing or positive by the participants in the second year of implementation. When data from both rounds are taken together, it is seen that division of school facilities is still the most favorable aspect of the reform initiative.

One middle school teacher's views about the division of school buildings are as the following:

"Younger students' sharing the same atmosphere with the older ones has caused negative effects in terms of students' behaviors. I think this change alone will serve as a measure for this negative interaction." This was a hoped-for result expected in the first year of the implementation (T52, 2013).

One change recipient's perceptions of the changes regarding elective courses are as follows: "To me, one of the best aspects of the reform is related to elective courses. Students are provided with the chance to choose the courses they like based on their interests and abilities. Their wishes are addressed in this way. This change will make significant contributions to their personality development" (T48, 2013).

\subsection{Gray Area}

In Table 3, change recipients' perceptions of the most difficult or complicated novelties to implement (2013) and the things remaining the same (2014) are presented comparatively. 
Table 3. The most difficult or complicated novelties to implement and the things remaining the same

\begin{tabular}{|c|c|c|c|}
\hline The most difficult or complicated novelties to implement (2013) & f & Things remaining the same (2014) & $\mathrm{f}$ \\
\hline Early schooling & 30 & Physical capacity of schools & 14 \\
\hline Increase in weekly teaching hours & 20 & Challenges caused by elective courses & 10 \\
\hline Mix-aged classrooms & 19 & Undivided school facilities & 9 \\
\hline Undivided school facilities & 13 & School readiness problems & 8 \\
\hline Elective courses & 12 & Lack of reference books & 6 \\
\hline Pre-school education & 12 & Misalignment between hours of the courses & 6 \\
\hline $5^{\text {th }}$ graders in middle schools & 11 & Teachers' professional growth & 6 \\
\hline Crowded schools and classrooms & 9 & Quality of education & 5 \\
\hline Increased load for students & 4 & Crowded classrooms & 4 \\
\hline Challenges of school orientation & 4 & Parents' perceptions of schools & 4 \\
\hline Inadequate space in schools & 3 & The same old story & 3 \\
\hline Termination of school counseling & 2 & School choice challenges & 2 \\
\hline Difficulty in making lesson schedules & 1 & Characteristics of vocational school students & 2 \\
\hline Increase in compulsory education & 1 & Boredom felt by early beginners & 2 \\
\hline \multirow{21}{*}{ Use of previous course books } & 1 & Lack of teaching staff members & 2 \\
\hline & & Academic achievement & 2 \\
\hline & & Shortage in budget & 2 \\
\hline & & $5^{\text {th }}$ graders' attending middle schools & 2 \\
\hline & & Pass-fail grading system & 2 \\
\hline & & Increase in the weekly teaching hours & 2 \\
\hline & & Resistance to change & 2 \\
\hline & & Bureaucratic barriers & 1 \\
\hline & & Communication problems & 1 \\
\hline & & No change in educational goals & 1 \\
\hline & & School governance & 1 \\
\hline & & Teachers' unawareness about system & 1 \\
\hline & & Decrease in class sizes & 1 \\
\hline & & Lack of classroom spaces & 1 \\
\hline & & Parents' unawareness of the system & 1 \\
\hline & & Diminishing interest in pre-school education & 1 \\
\hline & & Teachers' lacking enthusiasm & 1 \\
\hline & & Attending schools in remote locations & 1 \\
\hline & & Lack of communication among students & 1 \\
\hline & & Early beginners & 1 \\
\hline & & Increase in capacity of vocational high schools & 1 \\
\hline
\end{tabular}

According to the participants' perceptions, the most difficult or complicated novelties during the implementation period were early school beginning age, increase in weekly teaching hours, mix-aged classrooms, and undivided school facilities.

Furthermore, the aspects remaining the same, in the second year of the implementation, are the physical capacity of schools, challenges caused by elective courses, undivided school facilities and school readiness problems of 5 th graders. It is clearly seen that there are some school facilities which have been not divided/separated yet.

Here are some examples of the participants' perceptions: "Weekly teaching hours have been overtly increased; this load goes far beyond students' capacity" (A12, 2013).
"Physical capacity of the schools is not convenient for elective courses. Thus, these courses have been turned into «obligatory elective courses»" (A21, 2014). "The infrastructure and physical conditions of the schools were not ready for such a change. The change has become detrimental rather than beneficent for the schools" (T80, 2014).

\subsection{Black Area}

In Table 4, change recipients' perceptions of the most disruptive aspects of the change (2013) and the things going bad (2014) are presented comparatively. 
Table 4. The most disruptive aspects of the change and the things going bad/not progressing

\begin{tabular}{|c|c|c|c|}
\hline The most disruptive aspects of the change (2013) & $\mathrm{f}$ & The things going bad/not progressing (2014) & $\mathrm{f}$ \\
\hline Challenges caused by early beginners & 11 & Problems faced by early beginners & 9 \\
\hline $\begin{array}{l}\text { Misalignment between beginning and ending hours of the } \\
\text { classes }\end{array}$ & 11 & $5^{\text {th }}$ graders' attending middle schools & 8 \\
\hline Classroom teachers becoming surplus & 10 & Effects of school staff rotation & 6 \\
\hline Inconvenient physical conditions & 6 & Increase in weekly teaching hours & 5 \\
\hline School orientation & 5 & Elective courses & 4 \\
\hline Elective course system & 5 & No spacious areas at schools & 4 \\
\hline Decreasing interest in pre-school education & 4 & Compulsory secondary education & 4 \\
\hline Difficulties in the organization and operation of schools & 3 & Classroom teachers becoming surplus & 3 \\
\hline Fragmented school levels & 3 & Challenges faced by $1^{\text {st }}$-grade teachers & 3 \\
\hline Attending remote schools & 2 & Increase in daily course hours & 3 \\
\hline $5^{\text {th }}$ graders' attending middle schools & 2 & Crowded classrooms & 3 \\
\hline Termination of social club activities & 2 & Students' aimlessness and lack of ambition & 3 \\
\hline Student's clothing & 2 & School staff's challenges in adaptation to system & 2 \\
\hline Non-formal education & 2 & Decrease in teacher quality & 2 \\
\hline Increased workload for school staff & 1 & Termination of social club activities & 2 \\
\hline \multirow[t]{13}{*}{ Taking elective courses at different locations } & 1 & Problems faced by the division of school levels/buildings & 2 \\
\hline & & Teachers' transition to minor branches & 1 \\
\hline & & Heterogeneous classrooms & 1 \\
\hline & & Academic achievement standards & 1 \\
\hline & & Increase in misbehavior among students & 1 \\
\hline & & Challenges in the pre-school education & 1 \\
\hline & & Recurring changes in lesson schedules & 1 \\
\hline & & Placement in high schools & 1 \\
\hline & & Decrease in schooling ratios & 1 \\
\hline & & General state of education & 1 \\
\hline & & Students attending schools in remote locations & 1 \\
\hline & & Changes in pre-school curriculum & 1 \\
\hline & & Termination of performance homework & 1 \\
\hline
\end{tabular}

The findings demonstrated that challenges caused by early beginners, misalignment between beginning and ending hours of the courses and classroom teachers becoming surplus were regarded as the most disruptive aspects of the change. One participant stated her views as follows: "Teachers have difficulty in teaching early beginners because of high rates of absence. Their bones and muscles are not mature enough, which makes them disconnected to the school" (T77, 2013).

The increase in the weekly teaching hours has caused challenges in terms of beginning and ending hours of the courses: "I think 7th and 8th hours are not useful. Schools begin too early, and students have to attend 8 classes without any break. Both teachers and students get very tired" (T54, 2013). "This new system has affected classroom teachers in a negative way. Most of them have become surplus and have been appointed to different schools" (T68, 2013).

According to the participants' perceptions, problems faced by early beginners, 5th graders' attending middle schools and the effects of school staff rotation are seen among the things still going bad. Here is one teacher's view: "As the schooling age got down, early beginners' school readiness level is not suitable for primary schools. Learning process has been influenced negatively" (T24, 2014). Another one stated: "Early beginners often cry in the classroom" (T10, 2014).

\subsection{Future Expectations}

In Table 5, change recipients' perceptions of the future of the new system in 2013 vs. 2014 are presented comparatively. 
Table 5. The future and potential benefits of the new system

\begin{tabular}{|c|c|c|c|}
\hline The potential future benefits of the new system (2013) & $\mathrm{f}$ & Future of the new system (2014) & f \\
\hline More effective in all aspects & 16 & A new system-wide change in the short-run & 18 \\
\hline Promising no hope about future & 11 & The role of feedback in system's success & 18 \\
\hline Democratic education & 11 & Failure to attain the hoped-for goals & 13 \\
\hline Educated society & 10 & The same old story & 5 \\
\hline Decrease in negative interaction among students & 7 & Negative effects of compulsory middle and secondary school education & 5 \\
\hline Increasing schooling ratios & 4 & Useless change & 4 \\
\hline Better channeling to career paths & 4 & Failure in channeling students to vocations & 1 \\
\hline Increase in trained manpower & 3 & Paving way for vocational education & 1 \\
\hline Multi-path school transition & 3 & Decrease in quality of education & 1 \\
\hline Simplification of curriculum & 3 & Decrease in academic achievement & 1 \\
\hline Achievement and productivity & 3 & Increase in number of qualified people & 1 \\
\hline Institutionalization of school levels & 2 & Challenges of $5^{\text {th }}$ graders & 1 \\
\hline Easy access to guidance services & 2 & The new system will be established firmly & 1 \\
\hline Transition to social life earlier & 2 & Increasing intermediary manpower need & 1 \\
\hline Professionalization in school management & 2 & Increase in number of the unemployed & 1 \\
\hline Recruitment of new teachers & 2 & Increasing political intervention & 1 \\
\hline A quality education & 2 & Challenges of early school beginners & 1 \\
\hline Cultural and economic growth & 1 & Increase in the rate of literacy & 1 \\
\hline Non-formal education opportunity & 1 & & \\
\hline Focusing on each school level & 1 & & \\
\hline Balanced intermediary manpower need & 1 & & \\
\hline Decrease in competition among students & 1 & & \\
\hline Positive effect of fragmented level-less fatigue & 1 & & \\
\hline Elimination of exam stress for middle school students & 1 & & \\
\hline Increase in social activities & 1 & & \\
\hline Individualization in education & 1 & & \\
\hline
\end{tabular}

The participants' perceptions differed in terms of the expectations from the system. The advocates of the new initiative suggested that the new system will be more effective in all aspects in schools. It will pave the way for a more democratic and ethnically-sensitive education and a well-educated society. The participants stated their thoughts as: "Attending 12-year compulsory education will increase the education level of the society." (T74, T57, 2013). "Students and parents have received more democratic rights with this system; it will be beneficial I think" (T49, 2013). The opponents of the system, however, suggested that the system does not promise any hope about future. The participants also argued that the new initiative's success will mostly depend on the modifications in the basics of the system; otherwise it will fail to attain hoped-for goals.

Some participants' views were as follows: "I think the "4+4+4 education system" will be radically changed in the coming years; a new system, requiring important changes and revisions will have to be implemented" (A17, 2014). "If the physical capacity challenges are handled and multi-path school transition is designed well, the new system, to me, will be better than the previous one" (T4, 2014).

\section{Conclusion and Discussion}

The findings related to the white area are the division of school facilities, the former 5th graders' attending middle schools, introduction of elective courses, the simplified curriculum, provision of foreign language instruction at early stages, the revised schooling age for 1st grade and school staff's adaptation to the system. Consistent with these findings, elective courses are considered as the best part of the new system in Akpinar, Donder, Yildirim \& Karahan's [31] study.

In the gray area, it was found that school readiness problem of the early beginners and 5th graders, mix-aged classrooms, undivided school facilities, the increase in weekly teaching hours, the physical capacity of the schools, the challenges caused by elective courses were still problematic and did not progress. Boz [32] found that having 60-65 month-old students in their classrooms was a difficulty faced by teachers. Teachers had difficulties in implementing game and physical activities due to school-related factors, finding activities, and the class size. Kulekci [33] indicated that teachers found themselves in the system abruptly and encountered with 60-month old kids in the classrooms. Among the most important problems were self-care skills and negative judgments of the school [34]. Similarly, Ari [35] found that teaching students of different ages caused significant problems for teachers, and this implementation made them unhappy in the school.

Consistent with the findings in the white and black areas, Memisoglu \& İsmetoglu [36] found that besides positive aspects of the system, physical challenges, mix-aged classrooms, weekly teaching hours and multi-path school 
transitions were perceived as negative by school administrators. Ozdemir, Aydin \& Bozkurt [37] concluded that inadequate physical infrastructure, undivided school facilities, problems about elective courses and the quality of education were the same problems confronted in the first year of the new and the previous system.

In the black area, it was found that challenges posed by the "early beginners", misalignment between hours of the courses, classroom teachers becoming surplus, inconvenient physical conditions, problems faced by early beginners, 5 th graders' attending middle schools, effects of school staff rotation and increase in weekly teaching hours are the most disruptive aspects of the change, and these are still perceived as problematic aspects of the system. Ozden, Kilic, \& Aksu's [38] study demonstrated that teachers were not satisfied with the new system due to most of the aforementioned problems.

Finally, future expectations of the new system varied in terms of the potential effects of the reform initiative. The most outstanding ones included that the new system is more effective in all aspects, and it will increase the education level of the society. The reform initiative is thought to be effective in decreasing negative interaction among 'diverse-age-group' students and providing the opportunity to choose the field of interest in terms of school levels, which will result in a more democratic education. On the contrary, some participants believed that the new system is not promising, implying no hope regarding core issues such as teaching and learning processes in the long-run. Opponents also proposed that the new system will have a short life, and it will fail to attain the hoped-for goals. They thought that the new change is the same old story, not touching on the real needs and deep rooted problems of the education system. Aybek \& Aslan's [39] study concluded similar results. They reported that most of the teachers were not happy with the new system and that the new system bears a number of problems in terms of class size and infrastructure.

Some participants also offered solutions to the felt problems. As mentioned in different studies and the present study, for instance, Ari [35] and Epcacan [40], modifications in certain aspects of the change were regarded as critical to the success of the change. As implementers can closely observe the real problems of the reform, feedback from implementers may be the catalyst for the system's success, and it can be useful to develop specific strategies addressing the reform goals [41].

Given the overall findings of the case, it might be observed that despite some positive and progressing novelties, there are too many difficulties facing the change recipients. Furthermore, the change recipients felt isolated in the reform/change process. As an emotional response, teacher isolation during educational reforms is evidenced by several studies. For example, as pointed out by Flinders [42] "isolation of teachers should be of primary concern to policy makers...because isolation restricts opportunities for professional growth, it represents a potential barrier to the implementation of reform initiatives" (p.17). In the same way Fink [43], referring to feelings of isolation experienced by a group of teachers, stresses "an urgent need to build better bridges of understanding between policy makers and policy implementers" (p.105).

The isolation felt and the perceptions about the system's inability to solve the chronic problems of Turkish education system may likely affect change recipients' support for and commitment to change. This finding implies that the new system inherits some risks about the future of the change initiative. Analysis of micro-level elements, the software of the organization, should be one of the first starting points in the change process. The macro-level analysis may sometimes shadow some critical details hidden in micro-level elements. Lastly, MoNE must develop its own organizational change management know-how, which will shed light on what to do and how to act on reform initiatives, especially when dealing with the human side on the receiving end.

\section{Acknowledgements}

This study (titled as "A Preliminary Assessment of the Change Recipients' Perceptions of the " $4+4+4$ Reform Initiative": Has Anything Changed?") was presented as an oral presentation at $1^{\text {st }}$ International Eurasian Educational Research Congress which was held at İstanbul University, İstanbul, Turkey between 24-26 April 2014, and its abstract was published in the conference abstracts.

\section{REFERENCES}

[1] Liu, Y. \& Perrewé, P.L. Another look at the role of emotion in the organizational change: A process model. Human Resource Management Review. Vol. 15, Iss. 4, pp. 263-280, 2005.

[2] Townsend, T. Third millennium leaders: Thinking and acting both locally and globally, Leadership and Policy in Schools, Vol. 8, No. 4, pp. 355-379. 2009.

[3] Van Dam, K., Oreg, S., \& Schyns, B. Daily work contexts and resistance to organisational change: The role of leader-member exchange, development climate, and change process characteristics. Applied Psychology: An International Review, Vol. 57, No. 2, 313-334, 2008.

[4] Lewis, L. K. Organizational change: Creating change through strategic communication. Chichester, UK: Wiley-Blackwell, 2011.

[5] James, C. The importance of affective containment for teacher effectiveness and successful educational change. In C. Day \& J. C.-K. Lee (eds.), New understandings of teacher's work: Emotions and educational change. Dordrecht: Springer, 2011.

[6] Fullan, M. The new meaning of educational change. (4th ed.), New York: Teachers College Press, 2007.

[7] Armenakis, A.A. \& Harris, S.G. Reflections: Our journey in organizational change research and practice. Journal of Change Management, Vol. 9, No. 2, pp. 127-142, 2009.

[8] Toprak, M. \& Summak, M. S. Involvement in change and commitment to change: A study at public schools. 
International J. Soc. Sci. \& Education, Vol. 4, No.4, pp. 953-968, 2014.

[9] Rogiest, S., Segers, J., \& van Witteloostuijn, A. Climate, communication and participation impacting commitment to change. Journal of Organizational Change Management, Vol. 28, No. 6, pp. 1094-1106, 2015.

[10] Kavanagh, M.H., \& Ashkanasy, N.M. The impact of leadership and change management strategy on organizational culture and individual acceptance of change during a merger. British Journal of Management, Vol. 17, No. S1, pp. S81-S103, 2006.

[11] Hofstede, G., Hofstede, G. J., \& Minkov, M. Cultures and organizations: Software of the mind. (3rd Edition), NY-USA: McGraw-Hill, 2010.

[12] Aksit, N. Educational reform in Turkey. International Journal of Educational Development, Vol. 27, No. 2, pp. 129-137, 2007.

[13] Gagné, M., Koestner, R., \& Zuckerman, M. Facilitating acceptance of organizational change: The importance of selfdetermination. Journal of Applied Social Psychology, Vol. 30, No. 9, pp. 1843-1852, 2000.

[14] Smollan, R.K. \& Sayers, J.G. Organizational culture, change and emotions: A qualitative study. Journal of Change Management, Vol. 9, No. 4, pp. 435-457, 2009.

[15] Piderit, S.K. Rethinking resistance and recognizing ambivalence: A multidimensional view of attitudes toward an organizational change. Academy of Management Journal, Vol. 25, No. 4, pp. 783-794, 2000.

[16] Simsek, H. \& Yildirim, A. Turkey: Innovation and tradition. In Rotberg, I.C. (Ed.), Balancing change and tradition in global education reform, (2nd ed.) (pp. 149-180). Maryland: Rowman \& Littlefield Education, 2010.

[17] Harris, A. Reforming systems: Realizing the fourth way. Journal of Educational Change, Vol. 12, Iss. 12, pp. 159-171, 2011.

[18] Harris, A. Big change question: Does politics help or hinder education change? Journal of Educational Change, Vol. 10, No. 1, pp. 63-67, 2009.

[19] Van Veen, K. \& Sleegers, T. Teachers' emotions in a context of reforms: To a deeper understanding of teachers and reforms. In P.A. Schutz and M. Zembylas (eds.), Advances in teacher emotion research: The impact on teachers' lives, (pp. 233-251). Dordrecht: Springer, 2009.

[20] Little, J. W. Teachers' professional development in a climate of educational reform. Educational Evaluation and Policy Analysis, Vol. 15, No. 2, pp. 129-151, 1993.

[21] Cuban, L. Reforming again, again, and again. Educational Researcher, Vol. 19, No. 1, pp. 3-13, 1990.

[22] Hargreaves, A. \& Goodson, I. Educational change over time? The sustainability and nonsustainability of three decades of secondary school change and continuity. Educational Administration Quarterly, Vol. 42, No. 1, pp. 3-41, 2006.

[23] Harris, A. Leading system-wide improvement. International Journal of Leadership in Education: Theory and Practice, Vol. 15, No. 3, pp. 395-401, 2012.

[24] Çelik, Z.,\& Gür, B. Turkey's education policy during the AK Party era (2002-2013). Insight Turkey, Vol. 15, No. 4, pp.151-176, 2013.

[25] Creswell, J.W. Qualitative inquiry and research design: Choosing among five approaches. (2nd ed.), Thousand Oaks, California: Sage, 2007.
[26] Glesne, C. Personal communication at Ist EJER Congress in İstanbul, 24 April, 2014.

[27] MoNE, Retrieved February 18, 2013 from Ministry of National Education Provincial Directorate website, http:// www.gaziantep.meb.gov.tr.

[28] Ruspini, E. Longitudinal research and the analysis of social change. Quality \& Quantity, Vol. 33, No. 3, pp. 219-227, 1999.

[29] Agerfalk, P.J., Getting pragmatic. European Journal of Information Systems, Vol. 19, pp. 251-256, 2010.

[30] Lee, A.S., \& Nickerson, J.V. Theory as a case of design: lessons for design from the philosophy of science. In Proceedings of the 43rd Hawaii International Conference on System Sciences (SPRAGUE RH, Ed.), pp 1-8, IEEE Computer Society Press, Los Almitos, CA., 2010.

[31] Akpinar, B,. Donder, A., Yildirim, B. \& Karahan, O. Eğitimde $4+4+4$ sisteminin (modelinin) karşı program bağlamında değerlendirilmesi. M.Ü. Atatürk Eğitim Fakültesi Eğitim Bilimleri Dergisi, No. 36, pp. 25-39, 2012.

[32] Boz, T. Difficulties teachers experience in 4+4+4 new education system at first grade level. Unpublished master thesis, Middle East Technical University, Ankara, 2013.

[33] Kulekci, E. 4+ 4+ 4 eğitim sistemi kapsamında birleştirilmiş sınıf uygulamasına ilişkin öğretmen görüşlerinin değerlendirilmesi. Eğitim ve Öğretim Araştırmaları Dergisi, Vol. 2, No. 2, pp. 369-377, 2013.

[34] Kildan, A.O. \& Ahi, B. Evaluation of the adaptation of 66-72-month-old children to primary schools in Turkey. Procedia-Social and Behavioral Sciences, Vol. 116, pp. 2417-2423, 2014.

[35] Ari, A. Teacher views about the starting age of the first-grade elementary school. Educational Sciences: Theory \& Practice, Vol. 14, No. 3, pp. 1043-1047, 2014.

[36] Memisoglu, S.P. \& İsmetoglu, M. Zorunlu eğitimde 4+4+4 uygulamasına ilişkin okul yöneticilerinin görüşleri. Eğitim ve Öğretim Araştırmaları Dergisi, Vol. 2, No. 2, pp. 14-25, 2013.

[37] Ozdemir, G, Aydin, T., \& Bozkurt, A.T. Eğitim sistemindeki inovatif değişimlere yönelik ilköğretim okul yöneticilerinin görüşleri (Gaziantep ili örneği). Eğitim ve Öğretim Araştırmaları Dergisi, Vol. 2, No. 4, 70-77, 2013.

[38] Ozden, B., Kilic, R. \& Aksu, D. Sınıf öğretmenlerinin 12 yıllık $(4+4+4)$ zorunlu eğitime ilişkin uygulama öncesi ve bir y1l sonrası görüşleri. Uşak Üniversitesi Sosyal Bilimler Dergisi, Vol. 20, No. 20, pp. 181-202, 2014.

[39] Aybek, B., \& Aslan, S. Ortaokul öğretmenlerinin 4+ 4+ 4 kesintili zorunlu eğitim sistemine yönelik yaşadıkları sorunlar (Elazığ ili örneği). İlköğretim Online, Vol. 14, No. 2, pp. 770-786, 2015.

[40] Epcacan, C. İlkokul ve ortaokul öğretmen ve yöneticilerinin 4+4+4 eğitim sistemine ilişkin görüşleri (Siirt ili örneği). Ekev Akademi Dergisi, Vol. 18, No. 58, pp. 505-522, 2014.

[41] Colbert, R.D., Vernon-Jones, R., \& Pransky, K. The school change feedback process: Creating a new role for counselors in education reform. Journal of Counseling \& Development, Vol. 84, pp. 72-82, 2006.

[42] Flinders, D.J. Teacher isolation and the new reform. Journal of Curriculum and Supervision, Vol. 4. No. 1, pp. 17-29, 1988.

[43] Fink, D. The law of unintended consequences: The 'real' cost of top-down reform. Journal of Educational Change, Vol. 4, pp.105-128, 2003. 